\title{
USING EXPERT KNOWLEDGE TO SATISFY DATA NEEDS: MAPPING INVASIVE PLANT DISTRIBUTIONS IN THE WESTERN UNITED STATES
}

\author{
Bethany A. Bradley ${ }^{1}$ and David C. Marvin ${ }^{2}$
}

ABSTRACT.-Lack of knowledge about the distributions of plant and animal species can severely hamper management efforts. For invasive plants, distribution and abundance data can inform early detection and rapid response (EDRR) programs aimed at treating initial infestations. These data can be used to create invasion risk models at landscape and regional scales. Further, regional maps of invasive plant abundance are useful for communicating the scope of the invasive species problem to the public and policymakers. Here, we present a set of regional distribution maps for 10 problematic invasive plants in the western United States, created from the expert knowledge of weed managers in over 300 counties. Invasive plant experts identified infestations on paper, and the results were digitized into a regional GIS. Over $40 \%$ of requests were returned, resulting in maps with good spatial coverage and distribution data suitable for assessing invasive plant abundance across the western United States. Cheatgrass (Bromus tectorum) and Canada thistle (Cirsium arvense) were the most abundant and widespread of the surveyed species; however, the high concentrations and broad spatial extents of other invasive plants, such as hounds tongue (Cynoglossum officinale), white top (Lepidium draba), and Dalmatian toadflax (Linaria dalmatica), highlight the ongoing problems invasive species pose for western ecosystems, rangelands, and croplands. These results reinforce the critical role that regional mapping efforts can play in assessing and communicating invasion risk. This study suggests that knowledge about plant invasions exists locally and that experts are willing to participate in regional efforts to compile that information.

RESUMEN.-La falta de información sobre las distribuciones de especies de plantas y animales puede ser un serio impedimento para el manejo de dichas especies. En el caso de las plantas invasoras, la información sobre su distribución y abundancia puede guiar los programas de detección temprana y respuesta rápida (EDRR, por sus siglas en inglés) tendientes a combatir la infestación en sus etapas iniciales, y se puede emplear para crear modelos de riesgo de invasión a nivel regional o de paisaje. Además, los mapas regionales de la abundancia de plantas invasoras son útiles para comunicar la magnitud del problema de especies invasoras al público y a los legisladores. Aquí presentamos un conjunto de mapas de distribución regional para 10 plantas invasoras problemáticas del oeste de Estados Unidos, basados en el conocimiento experto de coordinadores del manejo de maleza en más de 300 condados. Los expertos en plantas invasoras identificaron las infestaciones por escrito, y los resultados se digitalizaron en un SIG (Sistema de Información Geográfica) regional. Se devolvieron más del $40 \%$ de las encuestas, posibilitando la creación de mapas con buena cobertura espacial y datos de distribución adecuados para la evaluación de la abundancia de plantas invasoras a lo largo del oeste de Estados Unidos. De las especies estudiadas, el bromo (Bromus tectorum) y el cardo cundidor (Cirsium arvense) fueron las más abundantes y tenían la distribución más extensa; no obstante, la alta concentración y amplia extensión espacial de otras plantas invasoras como la lengua de perro (Cynoglossum officinale), la draba (Lepidium draba) y la palomita dálmata (Linaria dalmatica) ponen de relieve lo persistente del problema que representan las especies invasoras para los ecosistemas, terrenos de pastoreo y tierras agrícolas del oeste de país. Estos resultados reafirman el papel crucial que pueden desempeñar los esfuerzos de cartografía regional al evaluar y dar a conocer el riesgo de invasión. Este estudio indica que la información sobre invasiones de plantas se encuentra a nivel local, y que los expertos están dispuestos a participar en los esfuerzos regionales para recopilar dicha información.

Biological invasions represent a substantial threat to ecosystems worldwide. Invasive plants often outcompete native plants, directly threatening some species and indirectly threatening others as habitat qualities change (Lockwood et al. 2007). Invasive species are a major component of global change (Vitousek et al. 1996, Mack et al. 2000, Millennium Ecosystem Assessment 2003) and cause harm to more than half of spe- cies listed in the Endangered Species Act (Wilcove et al. 1998). Invasive plants, in particular, can also affect ecosystem function by altering water cycling (Zavaleta 2000), changing microbial communities (Jordan et al. 2008), or increasing fire frequency (D’Antonio and Vitousek 1992). In addition to the biological consequences of invasions, invasive plants cause considerable economic losses by reducing crop yield and

\footnotetext{
${ }^{1}$ Department of Environmental Conservation, University of Massachusetts, Amherst, MA 01003. E-mail: bbradley@eco.umass.edu

2Department of Ecology and Evolutionary Biology, University of Michigan, Ann Arbor, MI 48109.
} 
rangeland productivity. Annual economic losses have been estimated at $\$ 2$ billion for western U.S. rangelands alone (DiTomaso 2000).

A major challenge for invasive plant management is identifying and preventing invasions before they expand into new landscapes. To prevent invasions, managers rely on early detection and rapid response (EDRR), or identifying and eradicating new infestations before they can gain a permanent foothold in a new landscape. Early detection of infestations is more effective when informed by knowledge of conditions that promote species invasions. For example, proximity to roads elevates invasion risk (Gelbard and Belnap 2003), and spatial models based on road distributions and other forms of land use can aid early detection and rapid response by predicting likelihood of future invasion (Bradley and Mustard 2006). At regional scales, such as the western United States, climatic conditions tend to be the best predictors of invasive plant distribution (Pearson and Dawson 2003). As a result, regional models based on empirical relationships between climate and invasive plant distributions have been used to identify invasion risk in land areas with climate conditions suitable for invasions (e.g., Rouget et al. 2004, Welk 2004, Thuiller et al. 2005, Schussman et al. 2006). Climaterelated risk assessments are also becoming increasingly important for forecasting future risk associated with climate change (e.g., Kriticos et al. 2003, Beaumont et al. 2009, Bradley 2009, Ibanez et al. 2009, Jarnevich and Stohlgren 2009, Bradley et al. 2010).

However, all of the model-based risk projections described above are highly dependent on distribution data. Without some starting knowledge of where invasive plants currently exist on a landscape, it is very difficult or impossible to model invasion risk, because models based on distribution data that capture only a subset of the total distribution can create biased results (Thuiller et al. 2004). Further, distribution data for invasive species that include abundance information (often used as a proxy for impact [Parker et al. 1999]), may be more useful for assessing overall risk (Kulhanek et al. 2011). Hence, efforts to develop comprehensive distribution and/or abundance data sets are critical for landscape and regional risk assessments and ultimately early detection and eradication efforts.

Unfortunately, comprehensive maps of invasive plant distribution are rare in the United States, and maps including invasive plant abun- dance rarer still. National distribution databases are at a resolution too coarse for useful distribution modeling (e.g., state presence/absence from USDA PLANTS Database; USDA-NRCS 2010), or are based on presence locations from herbarium records and contributed GPS points, which often miss substantial portions of species distribution (e.g., GBIF 2010). Regional collections of invasive plant presence points (e.g., Southwest Exotic Plant Mapping ProgramThomas and Guertin 2007, Early Detection \& Distribution Mapping System-EDDMapS 2010, Invasive Plant Atlas of the MidSouthIPAMS 2010) often have greater data coverage for specific regions, but they do not extend throughout the western United States (but see tamarix map-NIISS 2010). Many smaller areas such as national parks and some counties have collected comprehensive invasive plant distribution data based on vegetation surveys, but the limited land area of these data means that large portions of the regional distribution are missing. Further, Marvin et al. (2009) found that point distributions of invasive plants were biased towards areas with small rather than large infestations, possibly due to an emphasis on EDRR (early detection, rapid response) efforts. Incomplete or spatially biased coverage is problematic for assessing invasion risk, as missing distribution data result in biased and incorrect model projections (Thuiller et al. 2004).

Although the bulk of readily available data may be problematic in terms of spatial coverage, there is a considerable amount of invasive species distribution data scattered across the United States in individual computers and filing cabinets, and in the knowledge of local experts. Indeed, in a survey of invasive plant experts across the United States, Crall et al. (2006) uncovered nearly 200 unique databases on invasive plants. Information about invasive plant distributions exists, but it is dispersed amongst a wide range of experts, is based on varying collection methodologies, and is not often in a digital form. Hence, efforts to map regional invasive plant distributions would benefit from both compilation of existing digital distribution data sets (e.g., Crall et al. 2006, Holcombe et al. 2010) and elicitation of abundance estimates from expert knowledge (e.g., Maddox et al. 1985, Thoene 2002, Marvin et al. 2009).

Here, we describe the production of regional distribution and abundance maps for 10 highly problematic invasive plants across the western 


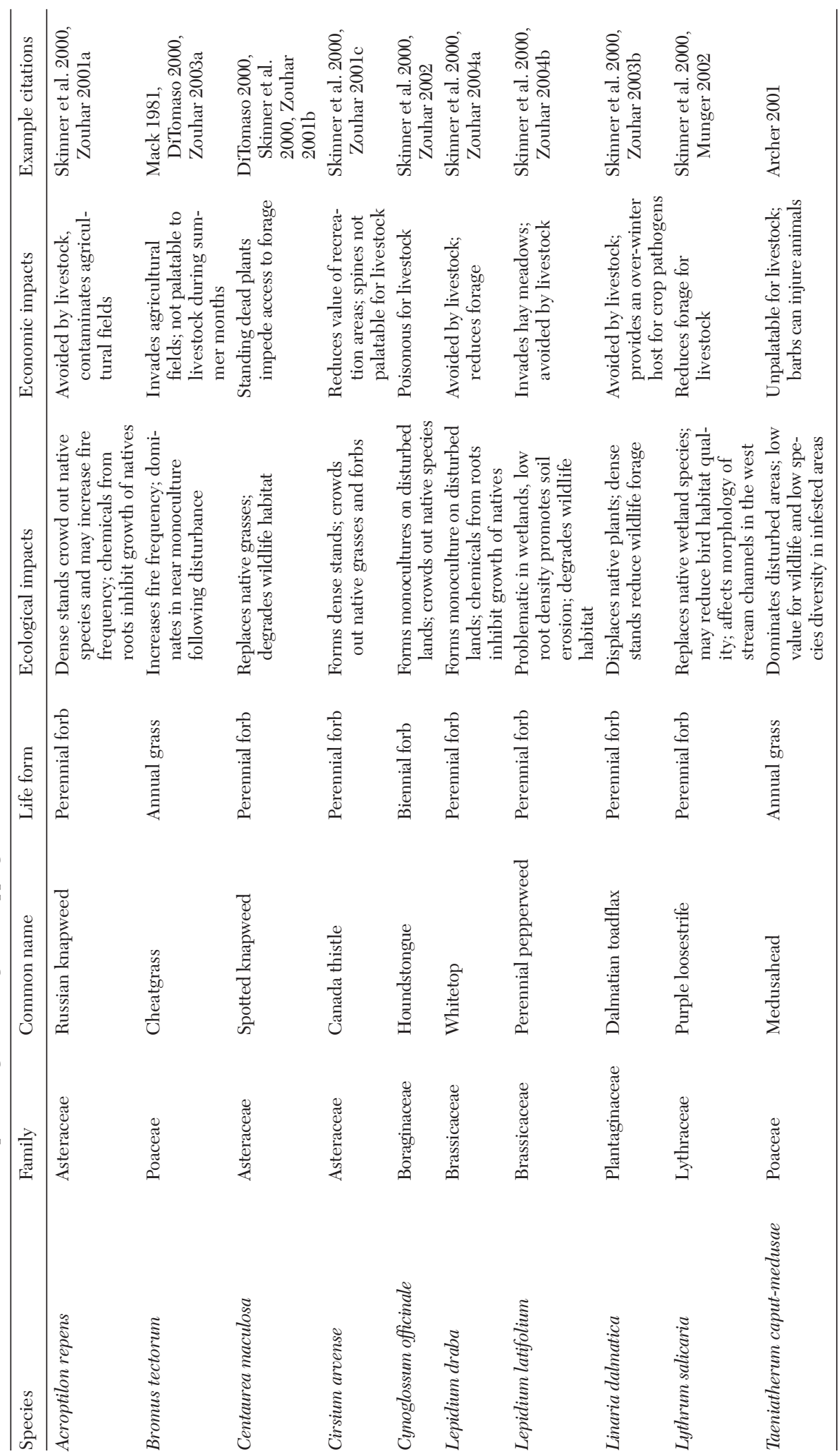


United States. Distribution and abundance information are based on expert knowledge provided by county weed supervisors employed by the U.S. Department of Agriculture. The data collected are regional in scale at a spatial resolution appropriate for comparison with climate. These results are useful for planning cross-jurisdictional treatments, raising awareness of the scope of the invasive species problem amongst the public and policymakers, and supporting science aimed at predicting invasion risk.

\section{Methods}

Targeted nonnative species were selected based on those viewed as important threats to ecosystems and as priorities for management in the western United States. Threat status was assessed based on reviews of the literature (e.g., Skinner et al. 2000), state noxious weed lists, and information available online (e.g., USDA Fire Effects Information System). Because the ultimate goal of the data collection was to provide information for climate-related risk assessment, selected species must have been widely introduced and present for many decades in the United States. This quality increases the likelihood that species have filled their "climatic niche" (Welk 2004), thereby reducing the risk of biasing model results based on the collected data (Thuiller et al. 2004). A list of the target species and examples of their impacts is shown in Table 1. Three common invasive species-tamarisk (Tamarix spp.), leafy spurge (Euphorbia esula), and yellow starthistle (Centaurea solstitialis) - were not included in this effort because they were mapped in 2002 using a similar methodology (Thoene 2002). Two other problematic species, buffelgrass (Pennisetum ciliare) and Sahara mustard (Brassica tournefortii), were included in the mapping effort but are not reported here due to a lack of sufficient response from experts in the Southwest, where those species are most problematic.

Invasive plants affecting primarily the western United States were targeted due to the availability of "weed supervisors" and/or Cooperative Weed Management Area (CWMA) officials employed by the U.S. Department of Agriculture (USDA). In the state of Nevada, invasive plant managers at the Bureau of Land Management (BLM) were contacted in addition to USDA weed managers, due to the abundance of BLM lands. Weed supervisors oversee identification, control, and eradication efforts within counties or CWMAs; therefore, they have considerable expert knowledge of the abundance and distribution of invasive plant species across broad spatial extents. Weed supervisors in a total of 731 counties across 15 western states were targeted for this mapping effort (Fig. 1A). Their names, mailing addresses, and contact information were acquired from state weed coordinators with the USDA.

We created maps of all 731 western counties, which included county borders, cities and towns, major roads, and water bodies. Overlaid on each map was a $4 \times 4$-km grid (Fig. 1B) comparable to the PRISM (Daly et al. 2002) interpolated climate data set at the same spatial resolution. For smaller counties, paper maps were printed on single $8.5 \times 11$-inch sheets of paper. Larger county maps used multiple sheets and/or larger paper. Although paper map production is somewhat unwieldy and resource intensive, paper maps were favored over digital maps due to the effort required from experts to input abundance estimates digitally across large spatial areas (Marvin et al. 2009), as well as lack of access and/or proficiency with internet applications in some counties.

Copies of the maps for each of the 10 target species were included in the mailed packet, along with color photographs of the target species, a cover letter explaining the project, instructions for completing the maps, and a self-addressed stamped envelope to return the maps. Maps were mailed in the winter of 2008-2009, a time when invasive plant managers are more frequently in the office because they aren't actively treating infestations. Responses were received through 30 June 2009.

Experts were asked to estimate distribution and abundance values on a qualitative scale ranging from "none present" to "many large infestations," including a "don't know" category. Although quantitative estimates of infestation acreage have been collected previously (Thoene 2002), we elected for a qualitative scale due to the difficulty in estimating infestation area, and the confusion as to what infestation area means in relation to percent cover. For example, does a 1-ha infestation equate to a 1-ha monoculture of the species or to 1-ha with some individuals present? Further, not all experts were trained to quantitatively estimate invasion area. The qualitative scale also provided a better 

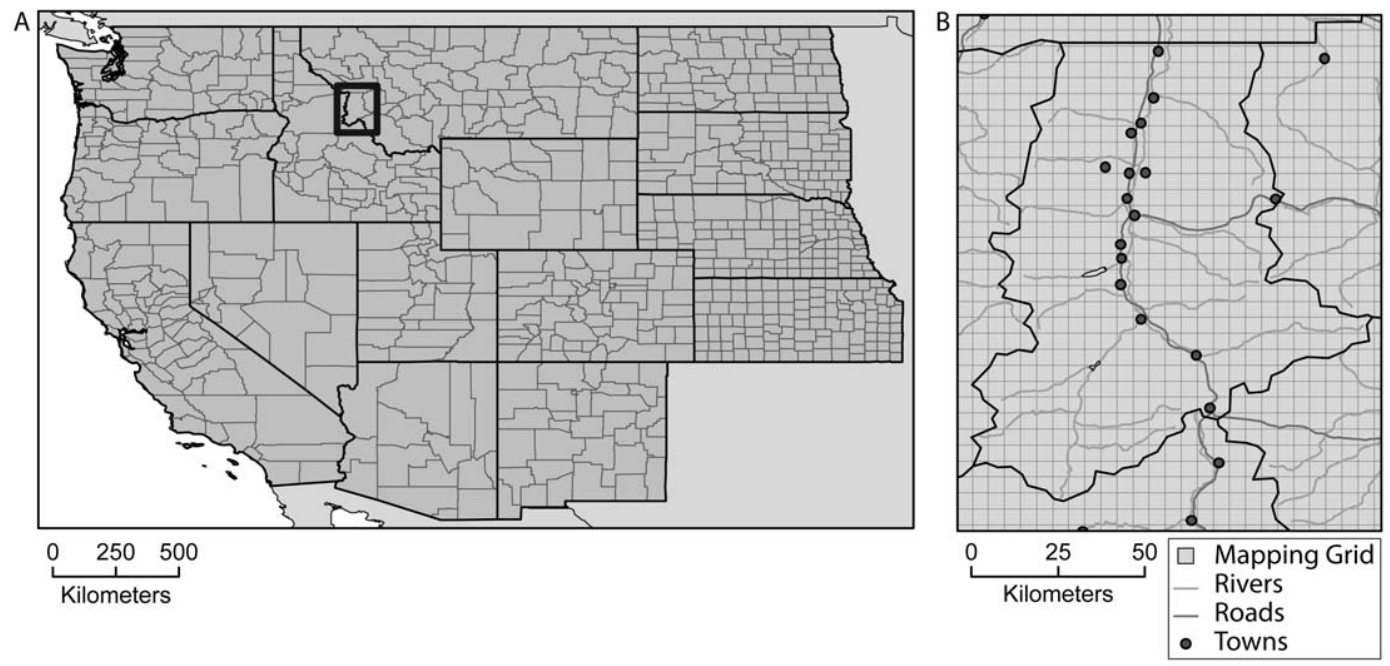

Fig. 1. Counties contacted for the regional mapping effort: A, gray county boundaries indicate the 731 counties contacted for expert information on invasive plant distributions; B, close up of Ravalli County, Montana, showing the size of the $4 \times 4-\mathrm{km}$ mapping grid.

gauge of how large a problem the target species were in the view of the invasive plant experts. A list of the qualitative rankings, as well as the symbology used to indicate each ranking within the $4 \times 4-\mathrm{km}$ grid cells, is presented in Fig. 2 .

Map responses were manually digitized into ArcGIS using a shapefile matching the $4 \times 4-\mathrm{km}$ mapping grid for each target species. Several county supervisors already had digital distributions of invasive species and completed the mapping exercise in electronic form. In these cases, point or polygon presence data were converted to qualitative abundance to provide a better understanding of what "presence" of the invasive species means. Using the digitized results, we created distribution maps for the 10 target species across the western United States. Because the responses were qualitative rather than quantitative, we cannot confidently estimate invaded area within the responding counties. However, we used conservative values for infested area within the $4 \times 4$-km grid cells to estimate invasion extents within the mapped area. The values were 100 ha or $1 \mathrm{~km}^{2}(6 \%)$ of invasive species dominance in cells labeled as "many large infestations" and 10 ha or $0.1 \mathrm{~km}^{2}$ $(<1 \%)$ in cells labeled as "many small infestations." Lower qualitative rankings were not converted to invasion extents because their impact on total estimated area would be minimal. In addition to estimating infested land area, we compared the percentage of responses marked as "rare but worried it will get worse" for each of the target species. Differences in this category could shed light on species likely to expand rapidly in the near term.

\section{RESULTS}

We received responses from 312 out of 731 counties, plus 3 BLM districts. The overall response rate was $43 \%$ of all counties. Response rates from several states, including Idaho, Montana, Utah, and Kansas, were well above 50\%. The land area mapped was 1.66 million $\mathrm{km}^{2}$ out of a total area of 3.87 million $\mathrm{km}^{2}$, or $43 \%$ of the land area of the western United States (Table 2).

The level of detail provided in the returned maps differed by county. Many managers provided detailed estimates of relative abundance throughout their counties (Fig. 2), while others provided a single estimate of abundance for the entire county. Single estimates of abundance for the entire county occurred more often for the most common species, and were typically marked as "many large invasions."

The relative abundances of the targeted invasive species within the mapped area are shown in Fig. 3. The 2 most abundant species in the region were cheatgrass (Bromus tectorum) and Canada thistle (Cirsium arvense). Cheatgrass was identified as present in over $60 \%$ of mapped grid 
Ravalli 1

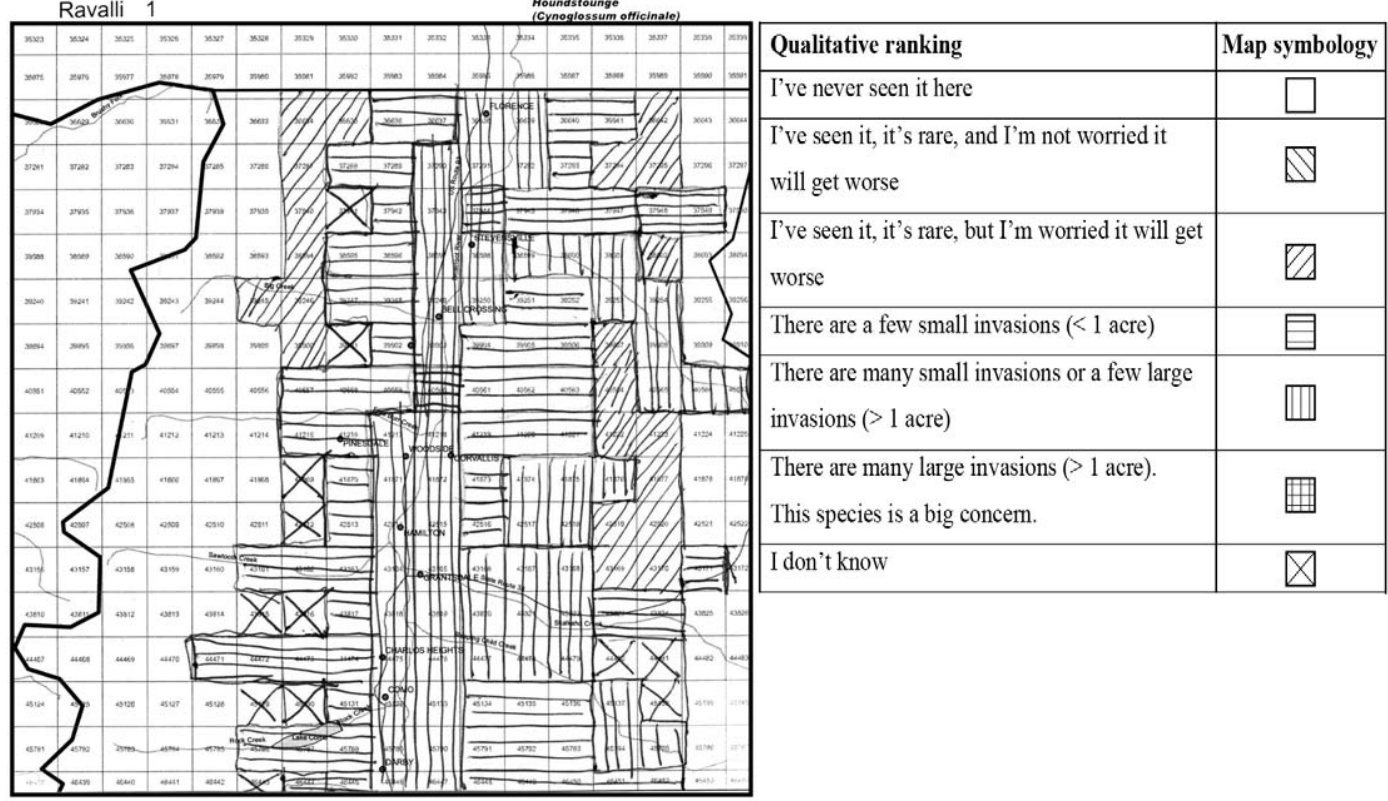

Fig. 2. Example of a completed map for northern Ravalli County, Montana, for Cynoglossum officinale.

TABLE 2. Response rates in terms of counties and land area mapped in each state.

\begin{tabular}{lcccccc}
\hline State & $\begin{array}{c}\text { Responding } \\
\text { counties }\end{array}$ & $\begin{array}{c}\text { Total } \\
\text { counties }\end{array}$ & $\begin{array}{c}\text { Response } \\
\text { rate }\end{array}$ & $\begin{array}{c}\text { Land area } \\
\text { mapped }\left(\mathrm{km}^{2}\right)\end{array}$ & $\begin{array}{c}\text { Total land } \\
\text { area }\left(\mathrm{km}^{2}\right)\end{array}$ & $\begin{array}{c}\text { Response } \\
\text { rate }\end{array}$ \\
\hline Arizona & 2 & 15 & $13 \%$ & 35,693 & 294,517 & $12 \%$ \\
California & 17 & 57 & $30 \%$ & 156,273 & 408,639 & $38 \%$ \\
Colorado & 30 & 62 & $48 \%$ & 134,202 & 269,620 & $50 \%$ \\
Idaho & 26 & 44 & $59 \%$ & 108,195 & 215,855 & $50 \%$ \\
Kansas & 52 & 105 & $50 \%$ & 121,455 & 212,889 & $57 \%$ \\
Montana & 31 & 57 & $54 \%$ & 197,668 & 381,353 & $52 \%$ \\
Nebraska & 44 & 93 & $47 \%$ & 97,367 & 200,282 & $49 \%$ \\
Nevada & 2 & 17 & $12 \%$ & 116,773 & 286,633 & $41 \%$ \\
New Mexico & 6 & 32 & $19 \%$ & 100,203 & 315,353 & $32 \%$ \\
North Dakota & 12 & 56 & $21 \%$ & 50,608 & 183,398 & $28 \%$ \\
Oregon & 12 & 36 & $33 \%$ & 124,144 & 251,415 & $49 \%$ \\
South Dakota & 31 & 66 & $47 \%$ & 100,227 & 199,931 & $50 \%$ \\
Utah & 16 & 29 & $55 \%$ & 116,471 & 219,816 & $53 \%$ \\
Washington & 20 & 39 & $51 \%$ & 89,029 & 174,276 & $51 \%$ \\
Wyoming & 10 & 23 & $43 \%$ & 113,131 & 253,306 & $45 \%$ \\
Total & 311 & 731 & $43 \%$ & $1,661,439$ & $3,867,283$ & $43 \%$ \\
\hline
\end{tabular}

aNevada mapping included 3 of 8 BLM districts in addition to counties. Mapped area including BLM response is included in the Land Area Mapped column.

cells, while Canada thistle was present in $39 \%$. Cheatgrass and Canada thistle abundance estimates were skewed toward larger infestations within each grid cell (Fig. 3A). Other species were approximately equally likely to occur rarely, or have small or large infestations across the mapped area. Purple loosestrife (Lythrum salicaria) was the least common of the mapped species, occurring in only $2 \%$ of mapped grid cells.
When qualitative abundance was converted to an estimate of infested land area (Fig. 3B), cheatgrass and Canada thistle remained the most widespread invasive species. Within the mapped area, cheatgrass infested an estimated $32,000 \mathrm{~km}^{2}$, while Canada thistle infested $12,000 \mathrm{~km}^{2}$. The other 8 species ranged from an estimated $200 \mathrm{~km}^{2}$ for purple loosestrife to $4000 \mathrm{~km}^{2}$ for spotted knapweed (Centaurea maculosa). 

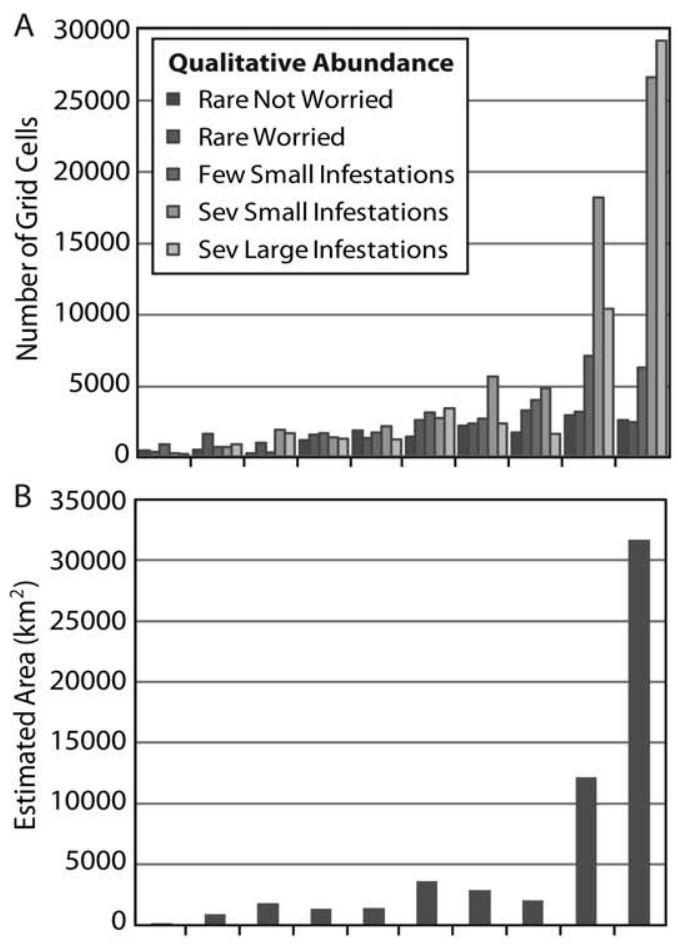

C

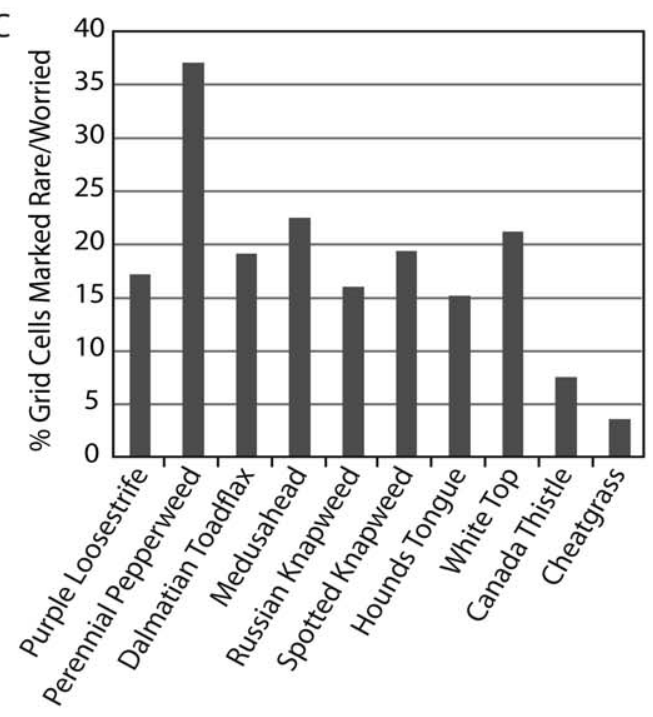

Fig. 3. Invasion extent of 10 problematic invasive species in the western United States: A, number of grid cells; B, estimated area of invasions within mapped counties in the western United States. Actual infestation areas are likely 2-3 times higher than reported here due to a $43 \%$ response rate and corresponding map coverage; $\mathrm{C}$, percentage of mapped grid cells identified as "rare but worried it will get worse."

We also calculated the percentage of mapped grid cells identified as "rare but worried it will get worse” (Fig. 3C). For the majority of species,
$15 \%-20 \%$ of mapped area was identified as rare/worried. In the cases of the 2 most abundant species, B. tectorum and Cirsium arvense, far fewer grid cells were identified as containing rare occurrences. However, in the case of perennial pepperweed (Lepidium latifolium), 37\% of mapped grid cells were marked as rare/worried, more than double the rate for all other species combined (Fig. 3C).

Distribution maps with qualitative abundance rankings for the 4 most extensive species (B. tectorum, Cirsium arvense, Cynoglossum officinale, and Lepidium draba) are shown in Figure 4. Bromus tectorum is pervasive across the western United States. Cirsium arvense is most problematic across northern states. Cynoglossum officinale invades primarily in the foothills of the Rocky Mountains and northern states. Lepidium draba is most extensive within the Great Basin Desert. Maps of the remaining 6 invasive species are presented in Figures 5 and 6.

\section{DisCUSSION}

Regional distribution maps are useful on many fronts. They are an important pedagogical tool for teaching the public about the scope of the invasive species problem. They provide sorely needed support for funding invasive plant management and prevention activities. Maps can assist management efforts across county and state boundaries by identifying invasion hot spots for priority control. Distribution maps are also critical for regional invasion risk assessments that can inform management prioritization.

Unfortunately, despite the strong need for invasive plant distribution data, regional-scale mapping efforts are rare in the western United States. The few examples of regional mapping efforts include a 1985 survey of counties that differentiated between absence, light infestations, and heavy infestations of yellow starthistle (Centaurea solstitialis) and Russian thistle (Acroptilon repens) in the United States (Maddox et al. 1985). Thoene (2002) surveyed weed supervisors in the western United States for acreage of leafy spurge (Euphorbia esula) and Centaurea solstitialis within $6 \times 6$-km USGS quarter quadrangles. A similar survey of weed supervisors accompanied by compilation of regional point occurrences was conducted for tamarisk (Tamarix ramosissima; WWCC 2002). Bradley and Mustard (2005) used remote sensing to map B. tectorum distribution at $1-\mathrm{km}$ resolution 

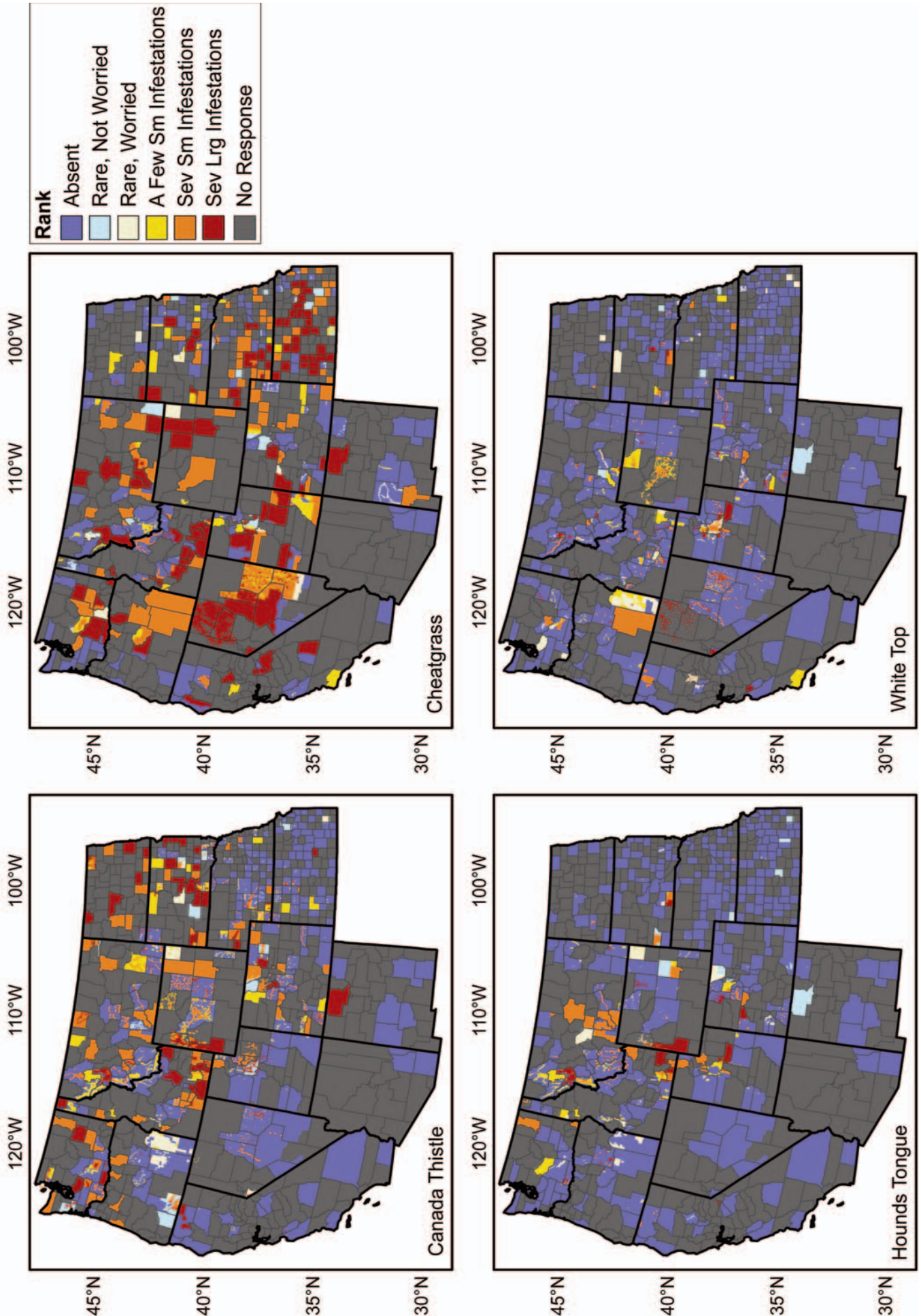

Fig. 4. Expert opinion maps of the distribution of Canada thistle (Cirsium arvense), cheatgrass (Bromus tectorum), hounds tongue (Cynoglossum officinale), and white top (Lepidium draba) in the western United States. These species are the four with the most grid cells identified as containing several large infestations. 

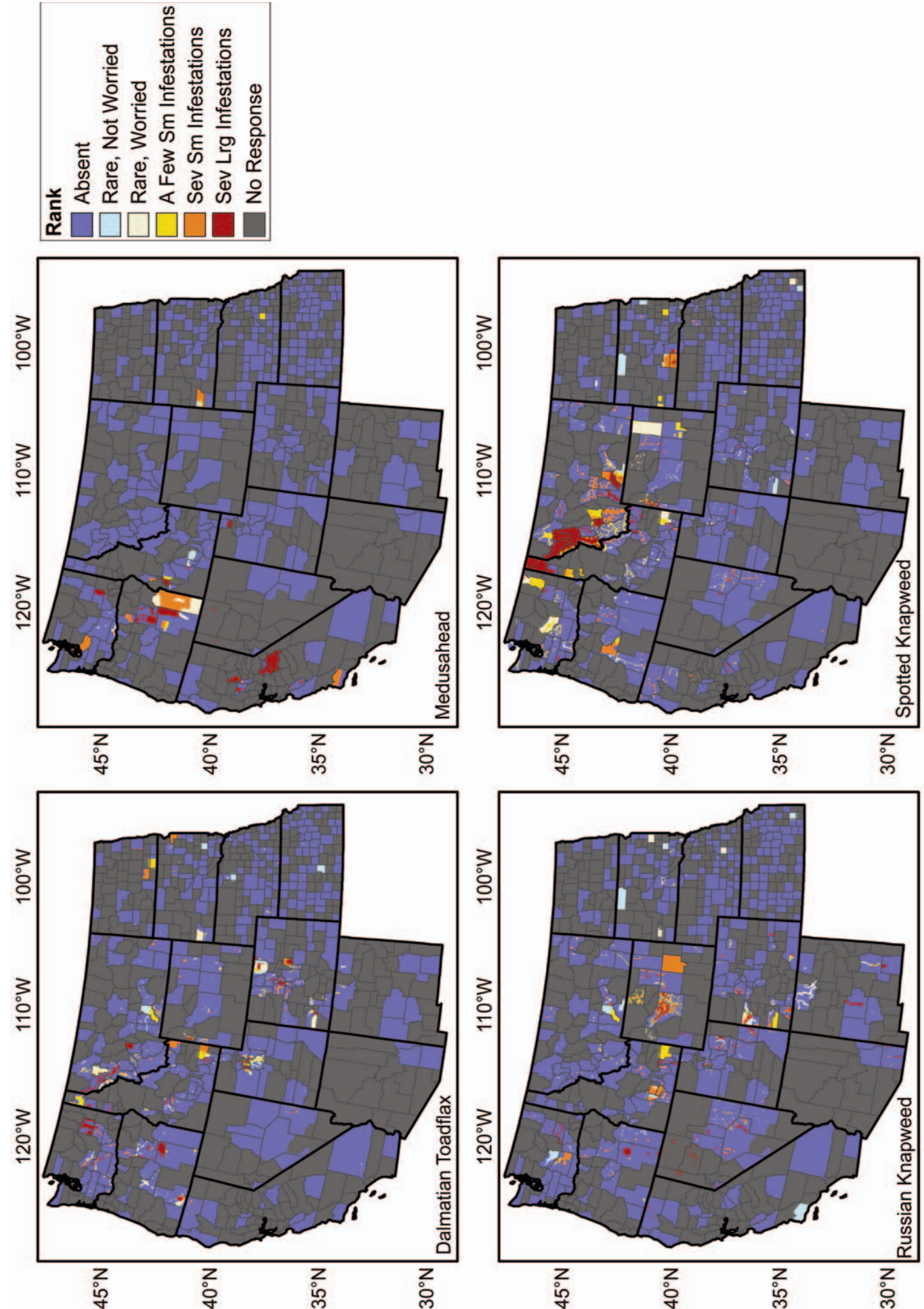

Fig. 5. Expert opinion maps of the distribution of Dalmatian toadflax (Linaria dalmatica), medusahead (Taeniatherum caput-medusae), Russian knapweed (Acroptilon repens), and spotted knapweed (Centaurea maculosa) in the western United States. 

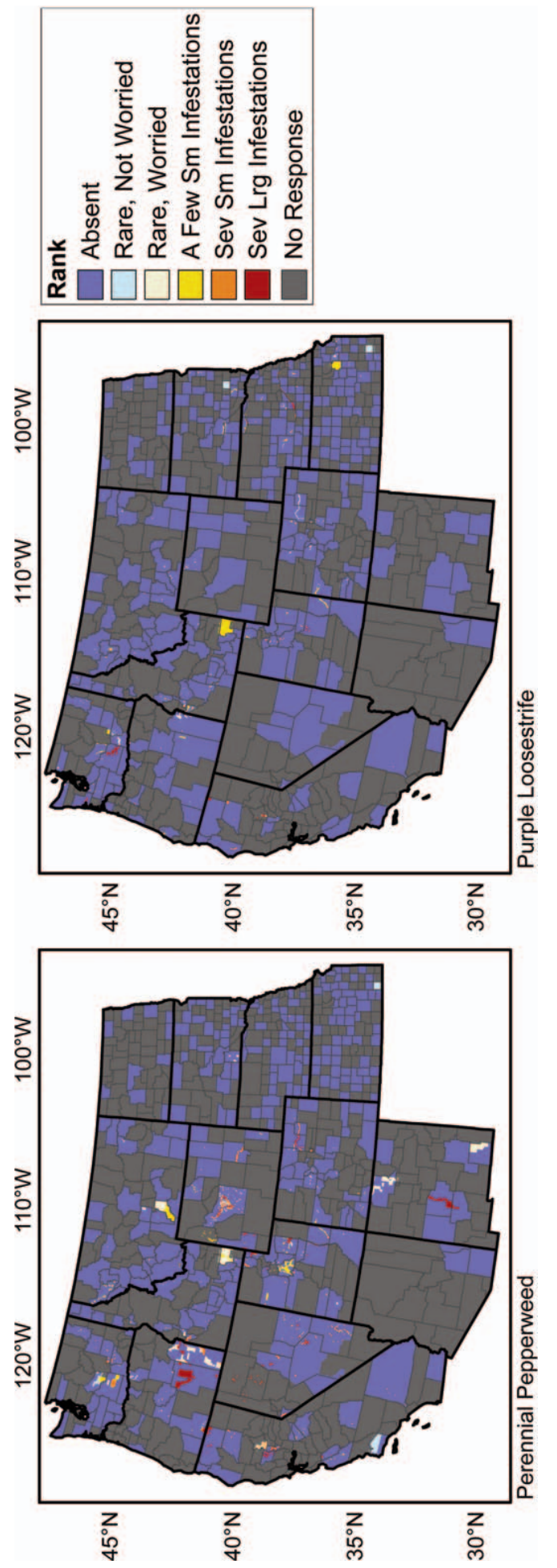

Fig. 6. Expert opinion maps of the distribution of perennial pepperweed (Lepidium latifolium) and purple loosestrife (Lythrum salicaria) in the western United States. within the Great Basin. Pitcairn et al. (2006) combined roadside surveys with expert opinion to map distribution and abundance of Centaurea solstitialis in California townships. Finally, the Colorado Department of Agriculture (http://www .colorado.gov/ag/csd) conducts regular surveys of county weed managers for over 20 invasive species. All told, the number of regional mapping efforts and diversity of species targeted has been extraordinarily small. Given the ecological and economic consequences of invasive species (Mack et al. 2000, Pimentel et al. 2005), it is remarkable how little we know about invasive plant distribution and abundance.

Most of what we do know about regional invasive plant distribution is derived from either herbarium records (e.g., the global biodiversity information facility, http://www.gbif.org), or compilations of contributed GPS points of invasive species locations (e.g., global invasive species information network; Simpson et al. 2009). Additional repositories of invasive plant distribution points also exist for the western United States, such as the southwest exotic mapping program (Thomas and Guertin 2007) and Oregon's weedmapper (http://www.weedmapper .org/). Unfortunately, herbarium records and occurrence data are unlikely to represent the full range of invasion, because point data are contributed rather than collected. Further, most occurrence records give no indication of abundance or impact, which, if known, might alter interpretations of invasion risk. Comprehensive regional distribution maps must be actively acquired and compiled, particularly in regions where point data and herbarium records do not exist.

This project asked already busy weed managers to volunteer several hours of their time to complete abundance and distribution maps. Managers received no financial incentive, nor were they required to complete the maps by their supervisors. Despite the lack of concrete incentive, the response rate was $43 \%$ overall and surpassed $50 \%$ in several states (Table 2). Although the time investment requested here was much lengthier, these response rates compare well to those found in other fields. For example, Kaplowitz et al. (2004) received a 32\% response rate to a 15-minute mailed survey to undergraduate students, while Asch et al. (1997) report an average response rate of $60 \%$ to mailed surveys of health-care professionals published in medical journals. It is likely that the high response rate amongst western weed managers 
stems from a strong vested interest in the western landscape and the belief that distribution data will ultimately aid management efforts through raised public awareness and improved invasion risk assessments. The response rate would likely be even higher if this type of project could offer financial incentive or had an agency mandate.

Although this research focused only on weed managers employed by the USDA, future surveys could include many other state and federal employees, as well as other experts involved in invasive plant councils (e.g., Marvin et al. 2009). The survey literature also suggests that follow-up e-mails and phone calls can significantly improve participation rates (Asch et al. 1997). Reminder e-mails were sent in this effort; however, reminder phone calls were not made and might have improved participation rates.

Implementation of this type of data collection and digitization of responses are relatively straightforward and low-cost. Data were easy to digitize because the maps used a uniform grid size and a limited number of abundance categories. The main costs involved organization, printing and mailing maps, digitizing responses, and the unpaid hours volunteered by numerous weed experts to complete the maps. The low cost and high response rate for this effort were strongly tied to the map resolution $(4 \times 4-\mathrm{km}$ grid cells) chosen for the project. Higher spatial resolution requires proportionally more effort to print, fill out, and digitize.

As with any collection of diverse expert knowledge, it is likely that some estimates of presence and abundance are incorrect. Ideally, this type of mapping process would include a component of random sampling within each county to validate the estimates (Barnett et al. 2007). Because we were unable to validate this map, overall accuracy is unknown. However, we can qualitatively observe that higher abundance areas tend to cluster regionally (Figs. 4, $5,6)$, suggesting that managers in adjacent counties are observing and reporting similar abundances of invasive species. The only exception to the spatially clustered pattern is for B. tectorum, which is identified as "abundant" and "absent" in several adjacent counties in Kansas, Nebraska, and South Dakota. This apparent error may result because the species is not a declared noxious weed in those states and, therefore, is not monitored except where it clearly impacts crop productivity. To better gauge confidence in the reported results, future surveys of this type should include a question about whether the targeted species are actively monitored.

The maps are consistent with the few other available estimates of distribution and abundance for species mapped here. For example, Hirsch and Leitch (1996) identify spotted knapweed (Centaurea maculosa) as a highly problematic and widespread weed in Montana, which is consistent with our findings (Fig. 5). Bradley and Mustard (2005) mapped B. tectorum throughout Nevada, western Utah, and southern Idaho, and their results are also consistent with ours (Fig. 4).

Similarly, it is also difficult to validate our estimates of total land area infested with invasive species (Fig. 3). The estimates presented here represent only $43 \%$ of the mapped area, so it is likely that actual infestation area is at least double the values presented here. For example, Hirsch and Leitch (1996) estimated that over $8000 \mathrm{~km}^{2}$ of Montana is infested by knapweeds, predominantly Centaurea maculosa. Our overall estimate for Centaurea maculosa was $4000 \mathrm{~km}^{2}$, primarily in Montana and Idaho. Also, Bradley and Mustard (2005) estimated that B. tectorum dominates $20,000 \mathrm{~km}^{2}$ of the Great Basin. Based on these maps, we estimate $7000 \mathrm{~km}^{2}$ within the same region, again suggesting that actual infestations are more than double the values reported in Figure 3 due to the $43 \%$ spatial area coverage.

Areas identified by weed experts as "rare but worried it will get worse” highlight potential short-term expansion of invasive species. The most widespread species, B. tectorum and Cirsium arvense, had much lower rates of identification as rare/worried (Fig. 3C), suggesting that these species have already expanded into most available land. Other species were more frequently identified as rare/worried, and L. latifolium, in particular, was identified as rare/worried $37 \%$ of the time (Fig. 3C). Invasive plant experts from Oregon to New Mexico expressed concern about this species, suggesting that it may be on the verge of a considerable expansion.

The resolution and spatial extents of this mapping effort were designed with an aim to correlate distribution to current climate conditions. For the purposes of modeling regional invasion risk in the western United States based on climatic suitability, the $43 \%$ spatial coverage is likely adequate. Although missing spatial data can bias distribution models (Thuiller et 
al. 2004), this is most problematic when major portions of the species' climatic range are not sampled. Given that the bulk of the western United States is evenly sampled (Figs. 4, 5, 6), these data should be useful for regional modeling efforts. One exception is portions of southern California, Arizona, and New Mexico, which had low response rates. Species with large portions of their range found in these areas were undersampled, which is why we elected not to present distribution maps for buffelgrass and Sahara mustard.

Overall, these maps highlight the magnitude of the invasive species problem in the western United States. Extensive land area has already been invaded, and substantial land area presumably remains at risk of future invasion. These data, particularly when coupled with regional modeling efforts, can inform allocation of resources and prioritization of management efforts. Compilations of regional distribution information are sorely needed to aid efforts to reduce nonnative species invasion.

\section{ACKNOWLEDGMENTS}

This project would not have been possible without the voluntary efforts of over 270 invasive plant managers and experts in the western United States. To all who contributed, we thank you. Darcie Ryan and Sylvia Dee assisted with digitizing data. David Wilcove contributed helpful advice and discussions. We gratefully acknowledge funding from the High Meadows Foundation at Princeton University and the Copeland Colloquium at Amherst College.

\section{Literature Cited}

ArCher, A.J. 2001. Taeniatherum caput-medusae [online]. Fire Effects Information System, Fire Sciences Laboratory, Rocky Mountain Research Station, USDA Forest Service. Available from: http://www.fs.fed.us/ database/feis/.

Asch, D.A., M.K. Jedrziewski, and N.A. Christakis. 1997. Response rates to mail surveys published in medical journals. Journal of Clinical Epidemiology 50:1129-1136.

Barnett, D., T. Stohlgren, C. Jarnevich, G. Chong, J. Ericson, T. Davern, and S. Simonson. 2007. The art and science of weed mapping. Environmental Monitoring and Assessment 132:235-252.

Beaumont, L.J., R.V. Gallagher, W. Thuiller, P.O. Downey, M.R. Leishman, and L. Hughes. 2009. Different climatic envelopes among invasive populations may lead to underestimations of current and future biological invasions. Diversity and Distributions 15:409-420.
BRADLEY, B.A. 2009. Regional analysis of impacts of climate change on cheatgrass invasion shows potential risk and opportunity. Global Change Biology 15: 196-208.

Bradley, B.A., AND J.F. Mustard. 2005. Identifying land cover variability distinct from land cover change: cheatgrass in the Great Basin. Remote Sensing of Environment 94:204-213.

2006. Characterizing the landscape dynamics of an invasive plant and risk of invasion using remote sensing. Ecological Applications 16:1132-1147.

Bradley, B.A., D.S. Wilcove, and M. OpPenheimer. 2010. Climate change increases risk of plant invasion in the eastern United States. Biological Invasions 12:1855-1872.

Crall, A.W., L.A. Meyerson, T.J. Stohlgren, C.S. Jarnevich, G.J. Newman, and J. Graham. 2006. Show me the numbers: what data currently exist for non-native species in the USA? Frontiers in Ecology and the Environment 4:414-418.

Daly, C., W.P. Gibson, G.H. TaYlor, G.L. Johnson, and P. PASTERIS. 2002. A knowledge-based approach to the statistical mapping of climate. Climate Research 22:99-113.

D’Antonio, C.M., And P.M. Vitousek. 1992. Biological invasions by exotic grasses, the grass fire cycle, and global change. Annual Review of Ecology and Systematics 23:63-87.

DiTomaso, J.M. 2000. Invasive weeds in rangelands: species, impacts, and management. Weed Science 48: 255-265.

EDDMAPS. 2010. Early detection \& distribution mapping system [online]. University of Georgia - Center for Invasive Species and Ecosystem Health. Available from: http://www.eddmaps.org/.

GELBARD, J.L., AND J. BELNAP. 2003. Roads as conduits for exotic plant invasions in a semiarid landscape. Conservation Biology 17:420-432.

[GBIF] GLOBAL BIODIVERSITY INFORMATION FACILITY. 2010 Global biodiversity information facility GBIF data portal [online]. Available from: http://www.gbif.org

HinsCH, S.A., AND J.A. LeITCH. 1996. The impact of knapweed on Montana's economy. Agricultural Economics Report No. 355, Agricultural Experiment Station, Fargo, ND.

Holcombe, T.R., T.J. Stohlgren, and C.S. Jarnevich. 2010. From points to forecasts: predicting invasive species habitat suitability in the near term. Diversity 2:738-767.

Ibanez, I., J.A. Silander, A.M. Wilson, N. Lafleur, N. TANAKA, AND I. TSUYAma. 2009. Multivariate forecasts of potential distributions of invasive plant species. Ecological Applications 19:359-375.

IPAMS. 2010. Invasive plant atlas of the MidSouth [online]. Geosystems Research Institute, Mississippi State University, MS. Available from: http://www.gri msstate.edu/ipams

JaRnevich, C.S., AND T.J. StohlgREn. 2009. Near term climate projections for invasive species distributions. Biological Invasions 11:1373-1379.

Jordan, N.R., D.L. Larson, AND S.C. Huerd. 2008. Soil modification by invasive plants: effects on native and invasive species of mixed-grass prairies. Biological Invasions 10:177-190.

Kaplowitz, M.D., T.D. Hadlock, and R. Levine. 2004. A comparison of web and mail survey response rates. Public Opinion Quarterly 68:94-101. 
Kriticos, D.J., R.W. Sutherst, J.R. Brown, S.W. Adkins, AND G.F. MaYwald. 2003. Climate change and the potential distribution of an invasive alien plant: Acacia nilotica ssp. indica in Australia. Journal of Applied Ecology 40:111-124.

KulhaneK, S.A., B. Leung, and A. Ricciardi. 2011. Using ecological niche models to predict the abundance and impact of invasive species: application to the common carp. Ecological Applications 21:203-213.

Lockwood, J., M. Hoopes, And M. Marchetti. 2007. Invasion ecology. Blackwell Publishing, Malden, MA.

MACK, R.N. 1981. Invasions of Bromus tectorum. 1. Into western North America: an ecological chronicle. AgroEcosystems 7:145-165.

Mack, R.N., D. Simberloff, W.M. Lonsdale, H. Evans, M. ClOUt, AND F.A. BAzZAZ. 2000. Biotic invasions: causes, epidemiology, global consequences, and control. Ecological Applications 10:689-710.

Maddox, D.M., A. Mayfield, And N.H. Poritz. 1985. Distribution of yellow starthistle (Centaurea solstitialis) and Russian knapweed (Centaurea repens). Weed Science 33:315-327.

Marvin, D.C., B.A. Bradley, and D.S. Wilcove. 2009. A novel, web-based ecosystem mapping tool using expert opinion. Natural Areas Journal 29:281-292.

Millennium Ecosystem Assessment. 2003. Ecosystems and human well-being: a framework for assessment. Island Press, Washington, DC.

MungeR, G.T. 2002. Lythrum salicaria [online]. Fire Effects Information System, Fire Sciences Laboratory, Rocky Mountain Research Station, USDA Forest Service. Available from: http://www.fs.fed.us/ database/feis/.

[NIISS] National Institute of Invasive Species Science. 2010. Tamarix cooperative mapping initiative (T-map) NIISS, Fort Collins, CO. Available from: http://www .niiss.org/cwis438/websites/T-map

Parker, I.M., D. Simberloff, W.M. Lonsdale, K. GoOdell, M. Wonham, P.M. Kareiva, M.H. Williamson, B Von Holle, P.B. Moyle, J.E. Byers, L. Goldwasser. 1999. Impact: toward a framework for understanding the ecological effects of invaders. Biological Invasions $1: 3-19$.

Pearson, R.G., and T.P. Dawson. 2003. Predicting the impacts of climate change on the distribution of species: are bioclimate envelope models useful? Global Ecology and Biogeography 12:361-371.

Pimentel, D., R. Zuniga, AND D. Morrison. 2005. Update on the environmental and economic costs associated with alien-invasive species in the United States. Ecological Economics 52:273-288.

Pitcairn, M.J., S. Schoenig, R. Yacoub, and J. Gendron. 2006. Yellow starthistle continues its spread in California. California Agriculture 60:83-90.

Rouget, M., D.M. Richardson, J.L. Nel, D.C. Le Maitre, B. EgOH, And T. MgIDI. 2004. Mapping the potential ranges of major plant invaders in South Africa, Lesotho and Swaziland using climatic suitability. Diversity and Distributions 10:475-484

Schussman, H., E. Geiger, T. Mau-Crimmins, and J. WARD. 2006. Spread and current potential distribution of an alien grass, Eragrostis lehmanniana Nees, in the southwestern USA: comparing historical data and ecological niche models. Diversity and Distributions 12:582-592.

Simpson, A., C. Jarnevich, J. Madsen, R. Westbrooks, C. Fournier, L. Mehrhoff, M. Browne, J. Graham,
AND E. SELLERS. 2009. Invasive species information networks: collaboration at multiple scales for prevention, early detection and rapid response to invasive alien species. Biodiversity 10:5-13.

Skinner, K., L. SMith, AND P. Rice. 2000. Using noxious weed lists to prioritize targets for developing weed management strategies. Weed Science 48:640-644.

Thoene, J.W. 2002. Implementation of a GIS for regional management of leafy spurge (Euphorbia esula) and yellow starthistle (Centaurea solstitialis) in the western United States. Department of Geography, University of Denver, Denver, CO.

Thomas, K.A., And P. Guertin. 2007. Southwest exotic mapping program 2007: occurrence summary and maps of select invasive, non-native plants in Arizona [online]. U.S. Geological Survey Open-File Report, U.S. Geological Survey. Available from: http://pubs .usgs.gov/of/2007/1277/.

Thuiller, W., L. Brotons, M.B. Araujo, and S. Lavorel. 2004. Effects of restricting environmental range of data to project current and future species distributions. Ecography 27:165-172.

Thuiller, W., D.M. Richardson, P. Pysek, G.F. Midgley, G.O. Hughes, And M. Rouget. 2005. Niche-based modelling as a tool for predicting the risk of alien plant invasions at a global scale. Global Change Biology 11:2234-2250.

USDA-NRCS. 2010. PLANTS Database [online]. National Plant Data Center, Baton Rouge, LA. Available from: http://plants.usda.gov

Vitousek, P.M., C.M. D’Antonio, L.L. Loope, and R. Westbrooks. 1996. Biological invasions as global environmental change. American Scientist 84:468-478.

WELK, E. 2004. Constraints in range predictions of invasive plant species due to non-equilibrium distribution patterns: purple loosestrife (Lythrum salicaria) in North America. Ecological Modelling 179:551-567.

Wilcove, D.S., D. Rothstein, J. Dubow, A. Phillips, And E. Losos. 1998. Quantifying threats to imperiled species in the United States. Bioscience 48:607-615.

[WWCC] Western Weed Coordinating Committee. 2002. Tamarisk distribution map. Available from: http://www.weedcenter.org/wwcc

ZavalETA, E. 2000. The economic value of controlling an invasive shrub. Ambio 29:462-467.

ZouHAR, K.L. 2001a. Acroptilon repens [online]. Fire Effects Information System, Fire Sciences Laboratory, Rocky Mountain Research Station, USDA Forest Service. Available from: http://www.fs.fed.us/database/feis/. 2001b. Centaurea maculosa [online]. Fire Effects Information System, Fire Sciences Laboratory, Rocky Mountain Research Station, USDA Forest Service. Available from: http://www.fs.fed.us/database/feis/. 2001c. Cirsium arvense [online]. Fire Effects Information System, Fire Sciences Laboratory, Rocky Mountain Research Station, USDA Forest Service. Available from: http://www.fs.fed.us/database/feis/. 2002. Cynoglossum officinale [online]. Fire Effects Information System, Fire Sciences Laboratory, Rocky Mountain Research Station, USDA Forest Service. Available from: http://www.fs.fed.us/database/feis/.

2003a. Bromus tectorum [online]. Fire Effects Information System, Fire Sciences Laboratory, Rocky Mountain Research Station, USDA Forest Service. Available from: http://www.fs.fed.us/database/feis/.

2003b. Linaria spp. [online]. Fire Effects Information System, Fire Sciences Laboratory, Rocky Mountain 
Research Station, USDA Forest Service. Available from: http://www.fs.fed.us/database/feis/.

.2004a. Cardaria spp. [online]. Fire Effects Information System, Fire Sciences Laboratory, Rocky Mountain Research Station, USDA Forest Service. Available from: http://www.fs.fed.us/database/feis/.

2004b. Lepidium latifolium [online]. Fire Effects Information System, Fire Sciences Laboratory, Rocky
Mountain Research Station, USDA Forest Service. Available from: http://www.fs.fed.us/database/feis/.

Received 4 January 2011 Accepted 13 June 2011 